\title{
Does objective measurement of tracheal tube cuff pressures minimise adverse effects and maintain accurate cuff pressures? A systematic review and meta-analysis
}

\author{
C. A. Hockey*, A. A. J. van Zundert†, J. D. Paratzł
}

\section{Summary}

Correct inflation pressures of the tracheal cuff are recommended to ensure adequate ventilation and prevent aspiration and adverse events. However there are conflicting views on which measurement to employ. The aim of this review was to examine whether adjustment of cuff pressure guided by objective measurement, compared with subjective measurement or observation of the pressure value alone, was able to prevent patient-related adverse effects and maintain accurate cuff pressures. A search of PubMed, Web of Science, Embase, CINAHL and ScienceDirect was conducted using keywords 'cuff pressure' and 'measure*' and related synonyms. Included studies were randomised or pseudo-randomised controlled trials investigating mechanically ventilated patients both in the intensive care unit and during surgery. Outcomes included adverse effects and the comparison of pressure measurements. Pooled analyses were performed to calculate risk ratios, effect sizes and 95\% confidence intervals. Meta-analysis found preliminary evidence that adjustment of cuff pressure guided by objective measurement as compared with subjective measurement or observation of the pressure value alone, has benefit in preventing adverse effects. These included cough at two hours (odds ratio [OR] 0.42, confidence interval [CI] 0.23 to 0.79 , $P=0.007$ ), hoarseness at 24 hours (OR $0.49, \mathrm{Cl} 0.31$ to $0.76, P<0.002$ ), sore throat (OR $0.73, \mathrm{Cl} 0.54$ to $0.97, P<0.03$ ), lesions of the trachea and incidences of silent aspiration ( $P=0.001$ ), as well as maintaining accurate cuff pressures (Hedges' $\mathrm{g} 1.61, \mathrm{Cl}$ 2.69 to $0.53, P=0.003$ ). Subjective measurement to guide adjustment or observation of the pressure value alone may lead to patient-related adverse effects and inaccuracies. It is recommended that an objective form of measurement be used.

Key Words: airway, intubation, tracheal, tracheostomy, intensive care

Many patients in the intensive care unit (ICU) or operating theatre (OT) will require intubation with either an endotracheal or tracheostomy tube. Cuff inflation is important to secure the tube position, to provide an adequate seal for ventilation and to prevent the aspiration of gastric and oral secretions. Currently a range of 20 to 30 $\mathrm{cmH}_{2} \mathrm{O}$ is regarded as safe; however out-of-range tracheal cuff pressures are common in patients with intratracheal intubation ${ }^{1}$. Over-inflation of the cuff can potentially impair tracheal mucosal blood flow ${ }^{2}$. This has been associated with tracheal injuries including mucosal inflammation, mucosal ischaemia, tracheal ulceration, stenosis, tracheo-oesophageal fistula, tracheomalacia and tracheal rupture ${ }^{3-10}$. Conversely, under-inflation of the cuff is associated with inadequate ventilation and microaspiration ${ }^{9,11-13}$, which may result in ventilator-acquired complications including pneumonia ${ }^{14}$.

\footnotetext{
* BPhty, Physiotherapist, Physiotherapy Department, Royal Brisbane and Women's Hospital, Brisbane, Queensland

+ MD PhD FRCA EDRA FANZCA, Professor of Anaesthesiology, Department of Anaesthesia and Perioperative Medicine, Royal Brisbane and Women's Hospital, Chairman of Anaesthesiology, Senior Staff Specialist, School of Medicine, University of Queensland, Brisbane, Queensland

¥ PhD FACP MPthy, Principal Research Fellow, Physiotherapy Department, Royal Brisbane and Women's Hospital, Principal Research Fellow, School of Medicine, University of Queensland, Principal Research Fellow, School of Allied Health Sciences, Griffith University, Brisbane, Queensland

Address for correspondence: Charlotte Hockey. Email: charlotteawarren@gmail.com Accepted for publication on April 29, 2016
}

Routine cuff pressure measurement and adjustment to keep the pressure within a recommended range has been claimed to be important in the prevention of adverse effects to the intubated patient ${ }^{15-17}$. However among the methods utilised, there is much variability ranging from subjective estimation techniques ${ }^{18-23}$, to more objective measures ${ }^{25-28}$ Despite this recommendation for routine measurement, cuff pressure monitoring is varied across sites, and recent literature has shown that dedicated guidelines or protocols and documentation are lacking ${ }^{15,29}$.

The objective of this systematic review was to examine whether adjustment of cuff pressure guided by objective measurement, as compared with subjective measurement or observation of the pressure value alone, was able to prevent patient-related adverse effects in mechanically ventilated patients with an artificial airway. Secondarily, the review compared the ability of the two forms of measurements to maintain accurate cuff pressure, despite variability in the target range between studies. Accurate cuff pressure was defined as a significant difference in cuff pressure between the two measurement groups.

\section{Materials and methods}

A systematic review of the published literature was conducted to investigate the effects of adjustment of cuff 
pressure guided by objective measurement, as compared with subjective measurement or observation of the pressure value alone, in mechanically ventilated patients in both the intensive care unit (ICU) and in the operating theatre (OT). Inclusion and exclusion criteria were determined and are listed in Table 1. As it was anticipated there would not be a large number of papers, it was decided a priori to include all studies fulfilling the inclusion criteria, regardless of the quality score. A protocol for this systematic review was registered and published on the PROSPERO database (42015016652). The PRISMA statement ${ }^{30}$ was followed to assure the quality of the reporting.

\section{Search strategy}

A comprehensive search strategy of the electronic databases PubMed, Web of Science, Embase, CINAHL and ScienceDirect was conducted. All databases were searched from 1970 to March 2015. Only studies after 1970 were reviewed to exclude older low volume, high pressure tracheal and tracheostomy tubes, which were replaced with high

Table 1

Inclusion/exclusion criteria for review

\begin{tabular}{|c|c|c|}
\hline & Inclusion & Exclusion \\
\hline Design & $\begin{array}{l}\text { Prospective randomised } \\
\text { controlled trials } \\
\text { Pseudo-randomised controlled } \\
\text { trials } \\
\text { Systematic reviews }\end{array}$ & $\begin{array}{l}\text { Case studies } \\
\text { Narrative reviews } \\
\text { Guidelines } \\
\text { Audits } \\
\text { Studies published } \\
<1970 \\
\text { Studies other than in } \\
\text { English or French }\end{array}$ \\
\hline Participants & $\begin{array}{l}\text { Adults or children mechanically } \\
\text { ventilated with an artificial } \\
\text { airway (tracheal tube or } \\
\text { tracheostomy tube) including } \\
\text { during surgery and in the } \\
\text { intensive care unit }\end{array}$ & $\begin{array}{l}\text { Animal models } \\
\text { Intubated with a } \\
\text { laryngeal mask airway }\end{array}$ \\
\hline Comparison & $\begin{array}{l}\text { Comparing objective cuff } \\
\text { pressure measurement and } \\
\text { adjustment to either no, or } \\
\text { subjective measurement } \\
\text { (based on human decision) } \\
\text { Comparing objective cuff } \\
\text { pressure measurement and } \\
\text { adjustment to observation } \\
\text { of the pressure without } \\
\text { adjustment }\end{array}$ & $\begin{array}{l}\text { Comparing two } \\
\text { objective cuff pressure } \\
\text { measurements } \\
\text { Comparing personnel } \\
\text { ability to accurately } \\
\text { inflate cuff } \\
\text { Comparing continuous } \\
\text { monitoring to single } \\
\text { objective measurement }\end{array}$ \\
\hline $\begin{array}{l}\text { Outcome } \\
\text { measures }\end{array}$ & $\begin{array}{l}\text { Primary } \\
\text { Associated adverse effects } \\
\text { including sore throat, } \\
\text { dysphagia, dysphonia, hoarse } \\
\text { voice, bleeding of the tracheal } \\
\text { mucosa, cough post-extubation } \\
\text { Rates of cuff over-inflation/ } \\
\text { under-inflation } \\
\text { Rates of silent aspiration } \\
\text { Secondary } \\
\text { Cuff pressures within the } \\
\text { recommended range }\end{array}$ & \\
\hline
\end{tabular}

volume, low pressure (HVLP) cuffs in the early 1970s. The keywords or search terms were as follows: ('cuff pressure' OR 'cuff volume' 'mechanically ventilated' OR 'mechanical ventilation' OR 'ventilated patient' OR ventilat* OR intubat* OR tracheostom* AND measure* OR record* OR monitor* OR observe* OR manage*). In addition we scanned citations from articles sourced within the database search. For the purpose of this review we defined cuff pressure measurement as any objective measure such as using a manometer/direct intracuff pressure gauge or pressurevolume loop closure. Subjective cuff pressure included estimation techniques such as pilot balloon palpation, auscultation technique, and measuring but not adjusting the cuff pressure within an appropriate range. Language limits were set to English and French. Animal studies were excluded.

\section{Selection criteria}

Studies selected for the meta-analysis were confined to those investigating mechanically ventilated patients both within the ICU and the OT with either an endotracheal tube or tracheostomy tube. Primary outcomes were associated adverse effects including self-reported sore throat, hoarse voice, tracheal mucosal injury visualised via fibreoptic bronchoscopy, and cough post-extubation at various timepoints. Secondary outcomes of interest were cuff pressures within the recommended range. In order to calculate 95\% confidence intervals $(\mathrm{Cl})$ and effect sizes, the studies were required to report means, standard deviations and sample size or sample size and $P$-value. To calculate odds ratios the studies were required to report numbers and percentages. To assess eligibility, two independent assessors $(\mathrm{CH}, \mathrm{JP})$ independently examined the titles and abstracts of the studies and consulted in case of disagreement. Figure 1 illustrates the article selection process.

\section{Assessment of methodological quality}

The quality of the methodological features of the nine studies were independently assessed and rated using the Physiotherapy Evidence Database (PEDro) scale. Criteria include specification of eligibility criteria (not scored), random allocation, concealed allocation, baseline similarity, therapist blinding, assessor blinding, measure of key outcomes $>85 \%$ of subjects, intention to treat, betweengroup statistical comparison and point measures, and measures of variability ${ }^{32}$. Only criteria two to 11 are scored in the PEDro scale. This is a reliable instrument for rating quality of randomised controlled trials (RCTs) ${ }^{32-33}$, based on a 0-10 point scale where a score of six or more indicates a trial of moderate to high quality. Following independent scoring and assessment, both reviewers $(\mathrm{CH}, \mathrm{JP})$ then discussed and verified the results. Consensus was achieved with open discussion between the investigators. The quality scoring for the included studies is shown in Table 2 (next page). 


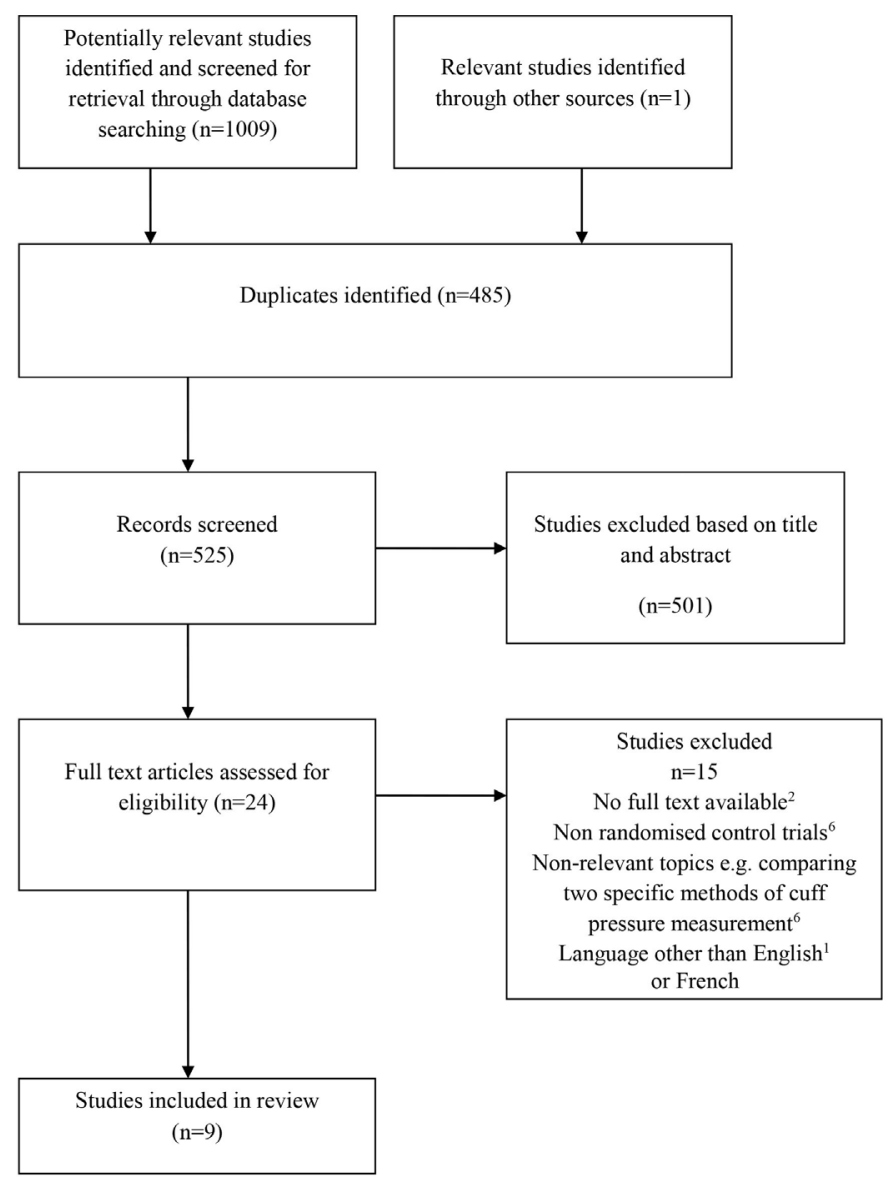

Figure 1: Flow diagram outlining the selection of studies for the review.

\section{Data Extraction and Analysis}

Two reviewers $(\mathrm{CH}, \mathrm{JP})$ independently performed and then cross-checked the data with regard to study design, intervention, and outcome measures. To compare results between trials, for continuous outcomes the unbiased effect size estimators (Hedges' $g$ ) with 95\% confidence intervals were calculated, using Comprehensive Metaanalysis software. Dichotomous outcomes were expressed as risk ratios with $95 \%$ confidence intervals. The data was pooled using the fixed effects model, however where heterogeneity was statistically significant ( $Q$ statistic $P<0.01$ ), the data was reanalysed using the random effects model. Meta-analysis was not possible for some outcomes due to heterogeneity in the method of measurement and infrequent outcome measures included in the studies. The data for these outcomes was reported descriptively. A summary of information is included in Tables 2 and 3, together with the score for quality assessment.

\section{Results}

From 1009 papers identified, 985 were eliminated on abstract review due to duplicate copies or meeting the a priori exclusion criteria (Figure 1). The 24 remaining studies were full-text reviewed and excluded if they were nonrandomised controlled trials $s^{25,26,34-37}$, not available in English ${ }^{38}$, full text not available ${ }^{39,40}$ or not on the actual topic ${ }^{23,41-44}$. This systematic review was based upon nine studies including seven RCTs ${ }^{45-51}$ and two pseudo-randomised controlled trials where interventions were compared but participants were not randomly allocated to groups ${ }^{52,53}$.

\section{Demographics and setting}

Specific details for selected studies are shown in Table 2. Studies were in either adult tertiary intensive care settings $(2)^{52,53}$, operating theatre $(6)^{45-50}$, both operating theatre and intensive care setting ${ }^{47}$, or intubated in medical wards $(1)^{51}$. Mean age overall was 43 years (range $22-70$ ). The ratio of males to females was approximately 1:1 (Table 3 ). Intubation time varied from 1.76 to 98.4 hours with the mean being 21.7 hours. Intubation time for ICU, OT and ICU, and ward patients was longer (range 8-98.4 hours) compared to intubation time in the OT (range 1.76-4.15 hours). The overall number of subjects was 1077 (n ranging from 24 to 509).

\section{Methodology}

The control groups used a variety of subjective measurement techniques and occasional objective measurements but adjustments were not guided by frequent objective measurement of pressures. The intervention group had objective measurements, most commonly using a manometer, and the pressures were either frequently or continuously adjusted using this method.

\section{Study quality and design}

Most prospective randomised controlled trials were well conducted but did not report the blinding of assessors ${ }^{51-55}$. Faults noted in lower scoring papers were nonspecification of eligibility criteria, lack of reporting of random allocation or concealed allocation, inequality at baseline, or blinding of assessors. As patients were heavily sedated or anaesthetised at this stage they were assumed to be blinded. Quality scores for the comparative studies are provided in Table 2 . All studies except one ${ }^{49}$ were single-centre which decreases external generalisability.

\section{Summary of findings}

Results are presented with Table 4 summarising the effect sizes. Meta-analysis was performed for differences in cuff pressures between groups (presented as a forest plot in Figure 2), incidence of cough at two and 24 hours, incidence of hoarseness at two and 24 hours, and incidence of sore throat at 24 hours.

\section{Cuff pressure measurement}

Six studies recorded the difference in intra-cuff pressure between the groups and a random effects model $(\mathrm{i} 2=95.3$, $P<0.001)$ found significantly lower cuff pressures in the 
Table 2

Physiotherapy Evidence Database (PEDro) ${ }^{31}$ scores of reviewed studies

\begin{tabular}{|c|c|c|c|c|c|c|c|c|c|c|c|}
\hline Study & $\begin{array}{l}\text { Random } \\
\text { allocation }\end{array}$ & $\begin{array}{l}\text { Concealed } \\
\text { allocation }\end{array}$ & $\begin{array}{l}\text { Baseline } \\
\text { similarity }\end{array}$ & $\begin{array}{l}\text { Subject } \\
\text { blinding }\end{array}$ & $\begin{array}{l}\text { Therapist } \\
\text { blinding }\end{array}$ & $\begin{array}{l}\text { Assessor } \\
\text { blinding }\end{array}$ & $\begin{array}{l}\text { Measure } \\
\text { of key } \\
\text { outcomes } \\
>85 \% \text { of } \\
\text { subjects }\end{array}$ & $\begin{array}{l}\text { Intention } \\
\text { to treat }\end{array}$ & $\begin{array}{l}\text { Between- } \\
\text { group } \\
\text { statistical } \\
\text { comparison }\end{array}$ & $\begin{array}{l}\text { Point } \\
\text { measures } \\
\text { and } \\
\text { measures } \\
\text { of } \\
\text { variability }\end{array}$ & $\begin{array}{l}\text { Physio- } \\
\text { therapy } \\
\text { evidence } \\
\text { database } \\
\text { score }(/ 10)\end{array}$ \\
\hline $\begin{array}{l}\text { Almarakbi } \\
\text { et al } 2014^{46}\end{array}$ & V & V & V & V & $x$ & V & V & V & V & V & 9 \\
\hline $\begin{array}{l}\text { Ansari et al } \\
2014^{45}\end{array}$ & $\mathrm{~V}$ & $\mathrm{~V}$ & $\mathrm{~V}$ & V & $x$ & $\mathrm{~V}$ & V & V & V & V & 9 \\
\hline $\begin{array}{l}\text { Liu et al } \\
2010^{49}\end{array}$ & $\mathrm{~V}$ & $x$ & V & V & $x$ & V & V & V & V & V & 8 \\
\hline $\begin{array}{l}\text { Morris et al } \\
2007^{52}\end{array}$ & $x$ & $x$ & $x$ & V & $x$ & $x$ & $\mathrm{~V}$ & $\mathrm{~V}$ & $\mathrm{~V}$ & $x$ & 4 \\
\hline $\begin{array}{l}\text { Rubes et al } \\
2014^{47}\end{array}$ & $\mathrm{~V}$ & V & $x$ & V & $x$ & V & $\mathrm{V}$ & $\mathrm{V}$ & $\mathrm{V}$ & $\mathrm{V}$ & 8 \\
\hline $\begin{array}{l}\text { Ryu et al } \\
2013^{48}\end{array}$ & $\mathrm{~V}$ & V & $\mathrm{V}$ & V & $x$ & V & $\mathrm{V}$ & $\mathrm{V}$ & $\mathrm{V}$ & $\mathrm{V}$ & 9 \\
\hline $\begin{array}{l}\text { Sajedi et al } \\
2002^{50}\end{array}$ & $\mathrm{~V}$ & $x$ & $\mathrm{~V}$ & V & $x$ & V & $\mathrm{V}$ & $\mathrm{V}$ & $\mathrm{V}$ & $\mathrm{V}$ & 8 \\
\hline $\begin{array}{l}\text { Sridermma } \\
\text { et al } 2007^{51}\end{array}$ & $x$ & $x$ & $x$ & V & $x$ & $x$ & $\mathrm{~V}$ & $\mathrm{~V}$ & $\mathrm{~V}$ & $\mathrm{~V}$ & 5 \\
\hline $\begin{array}{l}\text { Zand et al } \\
2008^{53}\end{array}$ & $x$ & $x$ & $x$ & V & $x$ & $x$ & $\mathrm{~V}$ & $\mathrm{~V}$ & $\mathrm{~V}$ & $\mathrm{~V}$ & 5 \\
\hline
\end{tabular}

intervention group (Hedges' $g$ 1.61, confidence interval [Cl] 2.69 to $0.53, P=0.003$ ) (Figure 2 ).

\section{Cough, hoarseness}

Random effects models found a significant effect for incidence of cough at two hours (odds ratio [OR] $0.43, \mathrm{Cl}$ 0.23 to $0.79, P=0.007)$ but not for 24 hours, (OR $0.80, \mathrm{Cl}$ 0.33 to $1.99, P=0.64)$. Although two studies ${ }^{46,48}$ found no difference between groups in hoarseness at two hours postoperatively (OR $0.67, \mathrm{Cl} 0.39$ to $1.16, P=0.15$ ), overall there was a significant decrease in hoarseness at 24 hours in the intervention group (OR 0.49, $\mathrm{Cl} 0.31$ to $0.76, P<0.002$ ).

\section{Sore throat, pain and dysphagia}

Three studies ${ }^{46,48,49}$ found significantly increased incidence of sore throat in the control group at 24 hours (OR 0.55, Cl 0.41 to $0.75, P=0.00$ ). Another study established pain by the visual analog scale (VAS) and found a significantly greater score for pain at two and six hours but not at 24 hours $^{45}$ (Table 4). One study investigated dysphagia at two and 24 hours and found no difference between groups ${ }^{48}$ (Table 4).

\section{Tracheal lesions}

Of the two studies that looked for tracheal injury, Liu et al $(P=0.043)^{49}$ and Sajedi et al $(P<0.001)^{50}$ found an increased incidence of tracheal injury in the control group. There was also a higher incidence $(P=0.002)$ of blood-streaked expectoration in the control group ${ }^{49}$ (Table 4).

\section{Silent aspiration}

A significant incidence of silent aspiration was found in the intervention group $(P<0.001)$ of one study ${ }^{47}$ (Table 4$)$.

Rates of over-inflation

One study ${ }^{52}$ examined rates of over-inflation $\left(>25 \mathrm{cmH}_{2} \mathrm{O}\right)$ and severe over-inflation $\left(>40 \mathrm{cmH}_{2} \mathrm{O}\right)$ and found no difference between groups (Table 4).

Intubation time and possible risk of bias

The majority of the studies ${ }^{46,48-50}$ had intubation times of approximately two hours, including all studies included in the meta-analyses reporting pain, sore throat, hoarseness, dysphagia and cough. The only outliers were Zand et al (98 hours) ${ }^{53}$ and Rubes et al (50 hours) ${ }^{47}$. Two studies ${ }^{45,51}$ reported an approximate intubation time for both groups, and one study ${ }^{52}$ did not report any time. Within studies, times between groups were homogeneous, except in the study by Rubes et al where there was a non-significant difference between groups ( $P=0.038$ ) (Table 3 ).

\section{Discussion}

This review provided preliminary evidence that adjustment of cuff pressure guided by objective measurement, as compared with subjective measurement or observation of the pressure alone can prevent adverse effects including hoarseness, sore throat, lesions of the trachea, and 


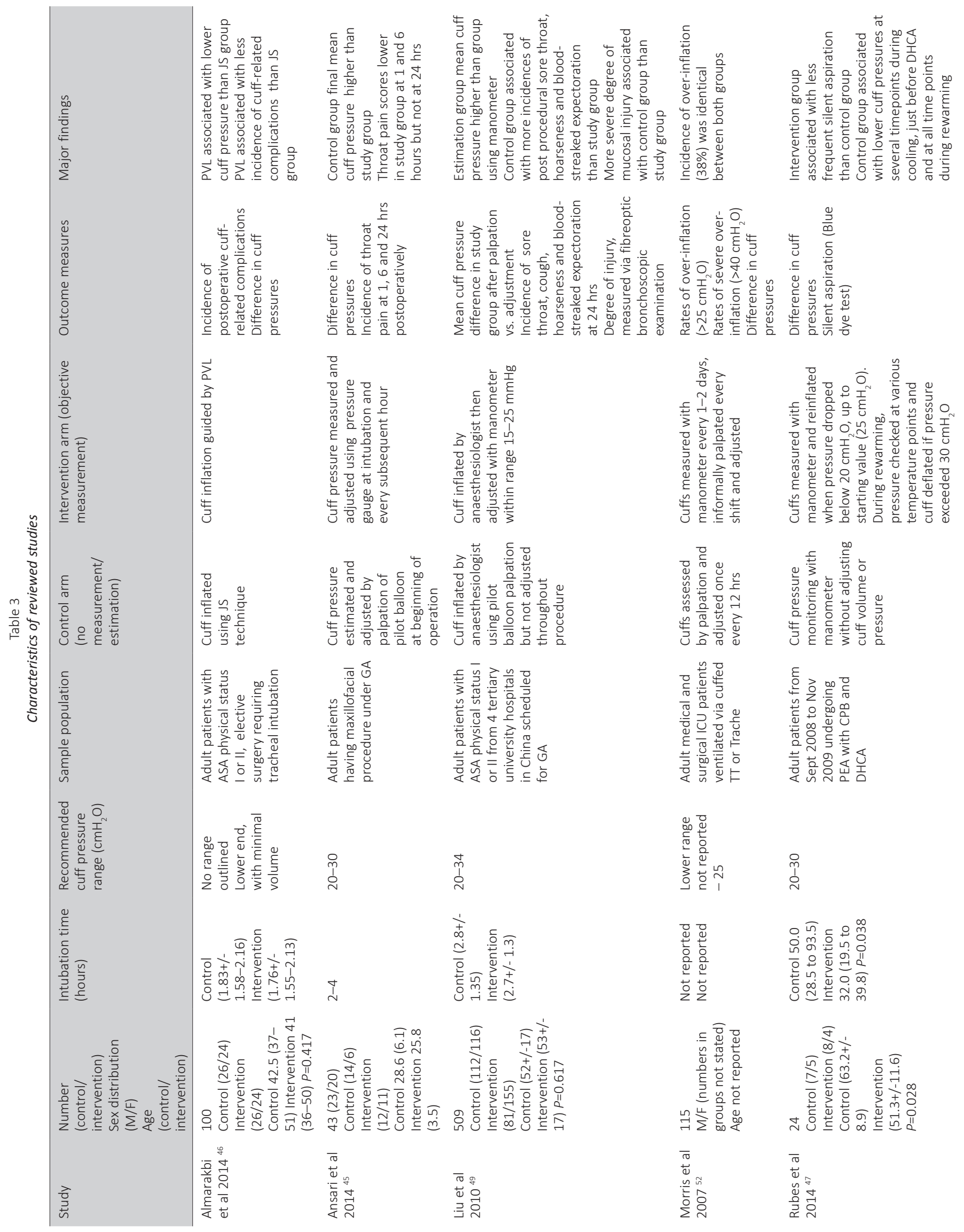




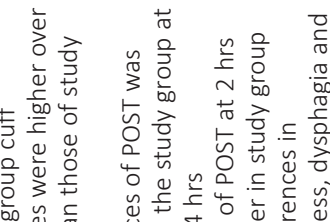

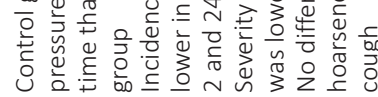

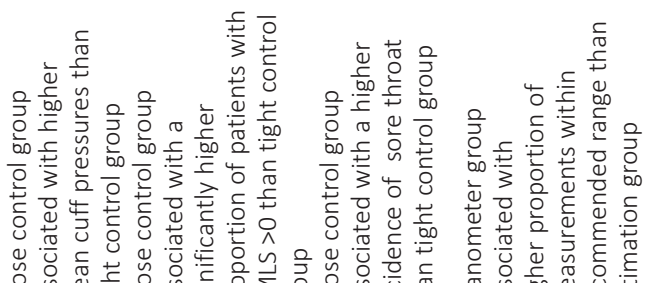

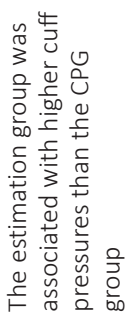

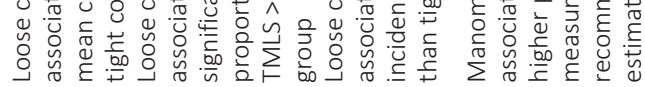

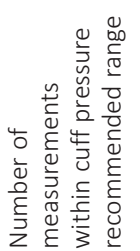

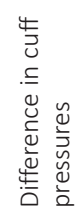

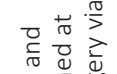 \\ 일 \\ 岕:

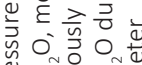

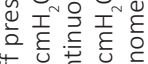

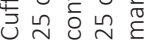

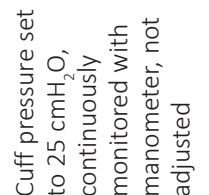

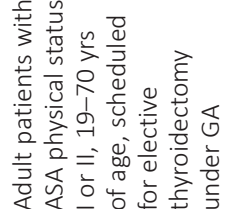

号

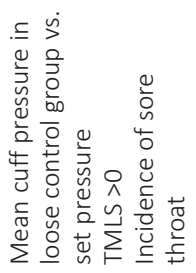

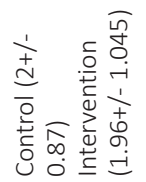

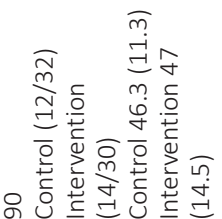

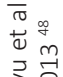

구 $\stackrel{m}{\stackrel{N}{N}}$
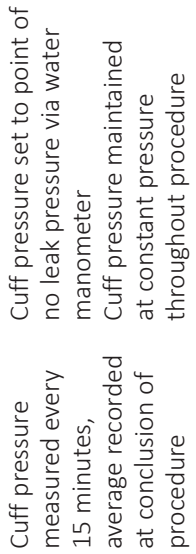

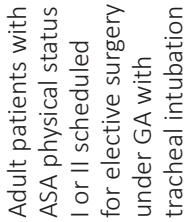
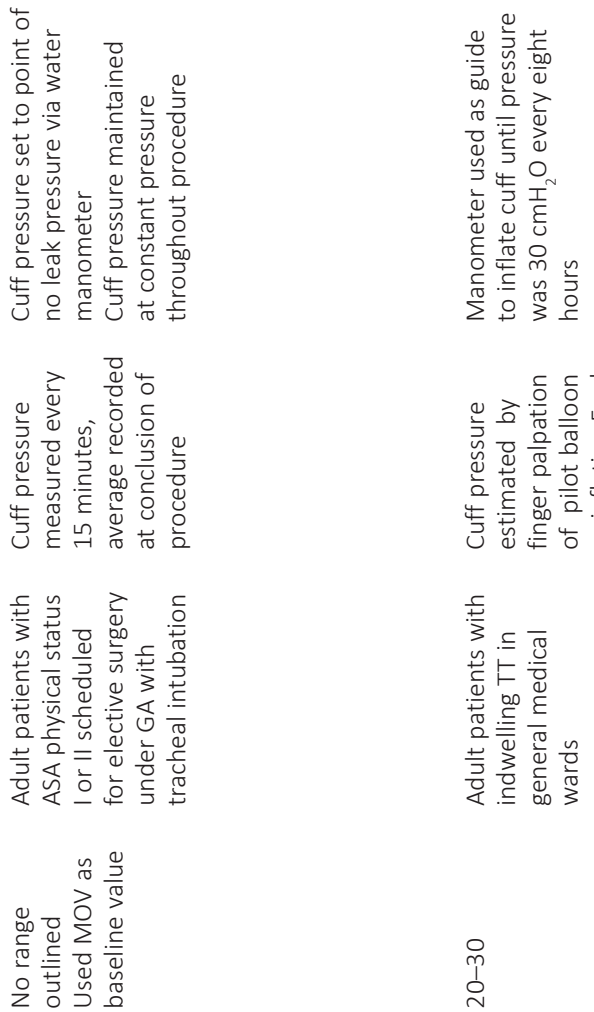

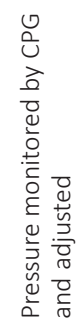

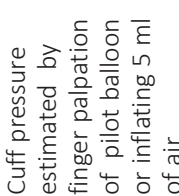
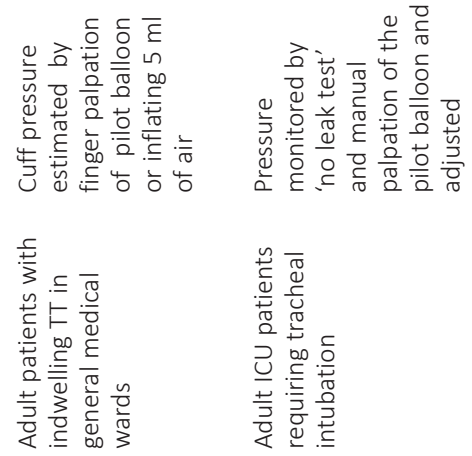

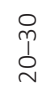

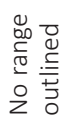
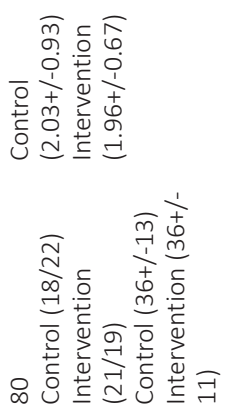

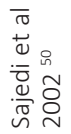

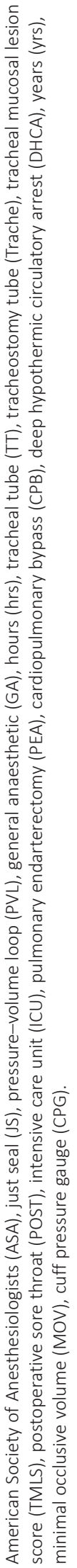


Study name

\begin{tabular}{|c|c|c|c|c|c|c|c|}
\hline & $\begin{array}{l}\text { Hedges' } \\
g\end{array}$ & $\begin{array}{l}\text { Standard } \\
\text { error }\end{array}$ & Variance & $\begin{array}{l}\text { Lower } \\
\text { limit }\end{array}$ & $\begin{array}{l}\text { Upper } \\
\text { limit }\end{array}$ & Z-Value & $P$ \\
\hline Ryu et al (2013) & -3.119 & 0.313 & 0.098 & -3.731 & -2.506 & -9.976 & \\
\hline Zand et al (2008) & -1.862 & 0.365 & 0.133 & -2.578 & -1.147 & -5.105 & \\
\hline Rubes et al (2014) & -1.495 & 0.449 & 0.202 & -2.375 & -0.614 & -3.326 & \\
\hline Anasari et al (2014) & -2.798 & 0.426 & 0.181 & -3.632 & -1.964 & -6.574 & \\
\hline Morris et al (2007) & 0.123 & 0.186 & 0.035 & -0.242 & 0.488 & 0.660 & \\
\hline Almarakbi et al (2014) & -0.673 & 0.204 & 0.042 & -1.073 & -0.273 & -3.299 & \\
\hline verall & -1.613 & 0.552 & 0.304 & -2.694 & -0.532 & -2.925 & \\
\hline
\end{tabular}

Statistics for each study
Hedges' $g$ and $95 \% \mathrm{Cl}$

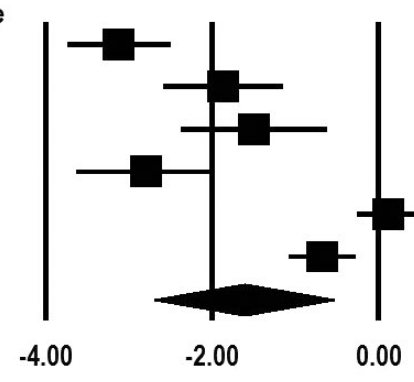

Favours Intervention

\section{Favours Control}

Figure 2: Differences in cuff pressures between groups. $\mathrm{Cl}=$ confidence interval.

incidences of silent aspiration, as well as maintaining accurate cuff pressures.

Multiple factors that contribute to patient-related adverse effects have been implicated in the literature. These include tracheal tube size, cuff position, type of tube, cuff contours, multiple attempts at tracheal intubation, duration of intubation, type of surgery, use of nasogastric tubes and, throat packs, some forms of lubrications, and downfolding of the epiglottis ${ }^{54-58}$. However the studies in this group were relatively homogeneous as regards intubation times and type of surgeries within groups. Other factors, while a source of variability, should have been counteracted by randomisation. However there is a need for larger studies with the analysis adjusted for confounders.

Only one study reported dysphagia as an outcome and found no difference between the two measurement groups at either two or 24 hours. These results were similar to a study of patients undergoing anterior cervical spine surgery, where dysphagia was related to the duration of neck retraction rather than cuff pressure ${ }^{59}$.

Sore throat is a common postoperative complaint following tracheal intubation. Causative factors reported in the literature include tracheal tube size ${ }^{56}$, cuff design ${ }^{60}$, certain lubricants containing local anaesthetic agents and steroids ${ }^{61}$, and high cuff pressures ${ }^{62}$. This review demonstrated a significant decrease in reports of sore throat or pain, suggesting a role of objective measurement. It is postulated that over-inflation may cause an increase in the cuff-tracheal contact area ${ }^{62}$, and as such a larger area of damage to the mucosa, due to ischaemia ${ }^{63}$. The incidence of sore throat has been shown to be relative to the area of cuff-tracheal contact $^{62}$ with the literature suggesting that cuff-pressure limitation may reduce the incidence of postoperative sore throat $^{62}$.

All adverse effects reported in the included studies were within the first 24 hours post-extubation. Conclusions therefore are unable to be drawn about any long-term effects that high cuff pressures may have.

All nine studies included in this review compared cuff measurements between groups. Meta-analysis of six studies demonstrated that objective cuff pressure measurement has a significant role in maintaining a lower cuff pressure, as compared to subjective techniques or observation of the pressure value alone.

Of note, whilst most of the studies reported cuff pressures as a direct comparison between the measurement groups, few of them reported a direct comparison between adverse events and targeted pressures. The one study that did look at the incidences of cuff pressure measurements within a recommended range, favoured the use of objective measurement in maintaining accurate cuff pressures ${ }^{51}$. There was significant variability among the recommended cuff pressure ranges within the studies included in this review. This variability is reflected in the literature, where there is no clear consensus of target cuff pressures ${ }^{29}$. It is often recommended to be between 20 and $30 \mathrm{cmH}_{2} \mathrm{O}^{2,14,64}$, however benchtop studies have suggested that cuff pressures may need to be much higher (up to $60 \mathrm{cmH}_{2} \mathrm{O}$ ) in order to limit microaspiration ${ }^{65}$. The application of higher pressures $\left(>30 \mathrm{cmH}_{2} \mathrm{O}\right.$ ) is of concern because of the risk of tracheal injury resulting from the obstruction of bloodflow in the tracheal mucosal wall2,66. These upper ranges have mostly been informed by animal studies, which conclude that cuff pressure monitoring is essential to avoid serious injury to the trachea ${ }^{63,67}$.

Tracheal cuff pressure tends to fluctuate with time. Diffusion of nitrous oxide during anaesthesia into the cuff of the tracheal tube results in an increase in cuff pressure almost immediately ${ }^{8}$, whilst prolonged surgical procedures (>4 hours) have been shown to result in significant variations in cuff pressure ${ }^{68}$. Using intermittent monitoring, Sole et al ${ }^{69,70}$ noted decreases in tracheal cuff pressure within four to 12 hours after adjustment of the pressure to $20 \mathrm{cmH}_{2} \mathrm{O}$. Similar findings were noted when cuff pressure was monitored 
Table 4

Summary of results

\begin{tabular}{|c|c|c|c|}
\hline Outcome Measure & Author & $\begin{array}{l}\text { Results (study } \\
\text { vs. control) }\end{array}$ & Favours \\
\hline \multicolumn{4}{|l|}{ Adverse effects } \\
\hline $\begin{array}{l}\text { Rates of over- } \\
\text { inflation }\end{array}$ & $\begin{array}{l}\text { Morris et al } \\
2007^{52}\end{array}$ & $\begin{array}{l}20 / 52 \text { (38\%) vs. } \\
24 / 63 \text { (38\%) } P=0.99\end{array}$ & NS \\
\hline $\begin{array}{l}\text { Rates of severe } \\
\text { over-inflation }\end{array}$ & $\begin{array}{l}\text { Morris et al } \\
2007^{52}\end{array}$ & $21 \%$ vs. $17 \% P=0.83$ & NS \\
\hline Dysphagia at $2 \mathrm{~h}$ & Ryu et al $2013^{48}$ & $\begin{array}{l}39(89) \text { vs. } 36 \text { (82) } \\
P=0.367\end{array}$ & NS \\
\hline Dysphagia at $24 \mathrm{~h}$ & Ryu et al $2013^{48}$ & $\begin{array}{l}31(71) \text { vs. } 34 \text { (77) } \\
P=0.467\end{array}$ & NS \\
\hline $\begin{array}{l}\text { Pain } 1 \mathrm{~h} \text { after } \\
\text { extubation (VAS) }\end{array}$ & $\begin{array}{l}\text { Ansari et al } \\
2014^{45}\end{array}$ & $\begin{array}{l}3.9(1.5) \text { vs. } 5.3(1.1) \\
P=0.002\end{array}$ & $\begin{array}{l}\text { Study } \\
\text { group }\end{array}$ \\
\hline $\begin{array}{l}\text { Pain } 6 \mathrm{~h} \text { after } \\
\text { extubation (VAS) }\end{array}$ & $\begin{array}{l}\text { Ansari et al } \\
2014^{45}\end{array}$ & $\begin{array}{l}3.1(1.5) \text { vs. } 4.5(1.3) \\
P=0.002\end{array}$ & $\begin{array}{l}\text { Study } \\
\text { group }\end{array}$ \\
\hline $\begin{array}{l}\text { Pain } 24 \mathrm{~h} \text { after } \\
\text { extubation (VAS) }\end{array}$ & $\begin{array}{l}\text { Ansari et al } \\
2014^{45}\end{array}$ & $\begin{array}{l}1.6(1.2) \text { vs. } 1.9(1.1) \\
P=0.4\end{array}$ & NS \\
\hline $\begin{array}{l}\text { Blood-streaked } \\
\text { expectoration }\end{array}$ & Liu et al $2010^{49}$ & $\begin{array}{l}9 \%(4) \text { vs. } 30 \%(11) \\
P=0.002\end{array}$ & $\begin{array}{l}\text { Study } \\
\text { group }\end{array}$ \\
\hline $\begin{array}{l}\text { Fibreoptic } \\
\text { bronchoscopic } \\
\text { examination } \\
\text { (degree of injury) }\end{array}$ & Liu et al $2010^{49}$ & $P=0.043$ & $\begin{array}{l}\text { Study } \\
\text { group }\end{array}$ \\
\hline $\mathrm{TMLS}>0$ & $\begin{array}{l}\text { Sajedi et al } \\
2002^{50}\end{array}$ & $\begin{array}{l}28 \% \text { vs. } 77.5 \% \\
P<0.001\end{array}$ & $\begin{array}{l}\text { Study } \\
\text { group }\end{array}$ \\
\hline \multicolumn{4}{|l|}{$\begin{array}{l}\text { Intra-cuff } \\
\text { Measurements }\end{array}$} \\
\hline $\begin{array}{l}\text { Mean TT CP } \\
\text { difference in } \\
\text { study group after } \\
\text { palpation vs. } \\
\text { adjustment }(\mathrm{mmHg})\end{array}$ & Liu et al $2010^{49}$ & $\begin{array}{l}43+/-23.3 \text { vs. } 20+/- \\
3.1 P<0.001 \\
N=236 \quad N=273\end{array}$ & $\begin{array}{l}\text { Study } \\
\text { group }\end{array}$ \\
\hline $\begin{array}{l}\text { Mean } \mathrm{CP} \text { in loose } \\
\text { control group } \\
\text { vs. set pressure } \\
\left(\mathrm{cmH}_{2} \mathrm{O}\right)\end{array}$ & $\begin{array}{l}\text { Sajedi et al } \\
2002^{50}\end{array}$ & $\begin{array}{l}81+/-17 \text { vs. } 23.4+/-3 \\
P<0.001 \\
N=40 \quad N=40\end{array}$ & $\begin{array}{l}\text { Study } \\
\text { group }\end{array}$ \\
\hline $\begin{array}{l}\text { Number of } \\
\text { measurements } \\
\text { within CP } \\
\text { recommended } \\
\text { range }\end{array}$ & $\begin{array}{l}\text { Sridermma et al } \\
2007^{51}\end{array}$ & $\begin{array}{l}181(90.5 \%) \text { vs. } 123 \\
(31.8 \%) \quad P<0.001 \\
(95 \% \mathrm{Cl} 2.44-3.32) \\
N=20 \quad N=39\end{array}$ & $\begin{array}{l}\text { Study } \\
\text { group }\end{array}$ \\
\hline
\end{tabular}

Tracheal tube (TT), cuff pressure (CP), hours (h), visual analog scale (VAS), tracheal mucosal lesion score (TMLS), non-significant (NS).

continuously ${ }^{1,71}$. Longer duration of intubation has been associated with greater decreases in pressure over time $\mathrm{e}^{1,72}$ and this is thought to be due to the cuff becoming less compliant $^{73}$. This change in pressures has implications for the timing of measurements. A recent qualitative review of cuff measurement practices found wide variability in frequency ranging from four-hourly to once a day ${ }^{29}$. This variability was reflected in this review with frequency of measurements ranging from continuous measurement to once every one to two days.

Two studies in the review reported on lesions of the trachea. It is thought that high cuff pressures affect perfusion of the tracheal mucosa, resulting in inflammation, ischaemia, ulceration, stenosis, necrosis, and ultimately, rupture of the tracheal mucosa ${ }^{74,75}$. Both studies directly visualised the tracheal mucosa via fibreoptic bronchoscopy, and reported mucosal injury. In addition Liu et a ${ }^{49}$ reported incidences of blood-streaked expectoration as a measure of tracheal damage. Both studies reported some degree of mucosal injury to the trachea in both measurement groups but found that the injury was more severe in the non-objectively measured group. Post mortem specimens of intubated patients have demonstrated extensive laryngeal and tracheal epithelial damage occurring as a result of both the intubation itself and the presence of the tracheal tube with an intubation period as short as one hour ${ }^{76,77}$. Damage was greatest in those patients who had been intubated the longest ${ }^{78}$. Intubation time in the studies included in this review ranged from one hour to five days. The times were homogeneous between the measurement groups in all studies. There appeared to be no association between length of intubation and reported adverse effects or tracheal damage. All studies included in meta-analysis of these outcomes came from the OT group and as such had relatively short intubation times, meaning that no comparisons could be made between the shorter intubation groups (OT) and the patients requiring longer intubation times (longer cases in OT and prolonged ICU and ward stays).

Only one study in the review looked at the incidence of silent aspiration as a reported adverse effect. They found objective cuff pressure measurement to be beneficial in preventing silent aspiration. Similarly Nseir and colleagues ${ }^{79}$ demonstrated that continuous cuff pressure monitoring was effective in reducing the risk of microaspiration and subsequently ventilator-associated pneumonia (VAP). Cuff pressure control to prevent microaspiration is often included in the bundle of care to prevent VAP ${ }^{80,81}$. The results from this review support the use of regular objective cuff measurement as part of a VAP prevention strategy.

From the overall results of this review there is strong evidence that adjustment of cuff pressure guided by objective measurement as compared with subjective measurement or observation of the pressure alone has beneficial effects in maintaining accurate cuff pressures, despite the lack of a clear consensus regarding a recommended cuff pressure range. There does appear to be some moderate evidence that objective measurement is beneficial in preventing 
cough, hoarseness, sore throat, lesions of the trachea, and incidences of silent aspiration. The results clearly support that cuff pressure adjustment be guided by use of an objective device as it has a direct impact on patient-related outcomes for the prevention of adverse effects.

This systematic review and meta-analysis has some limitations, namely the small number of participants included in the studies and heterogeneity of both methodology and outcome measures. Initial criteria excluded comparison of continuous or automated monitoring. These forms of monitoring are becoming more common and need to be investigated further. Generalisation of results may be limited as most of the trials were conducted within a theatre, where intubation time is shorter relative to stays in the ICU. This review did not seek to outline the specifics of recommended cuff pressure range, frequency of measurements or objective device used. Further definitive studies are required to inform the specifics associated with this practice.

Future trials should focus on specific measurable targets, such as a recommended cuff pressure range, and be powered for meaningful short- and long-term outcomes. It is important to include a priori a more diverse population of intubated patients in order to investigate which population of patients receives most benefit from cuff pressure measurement.

This review has found preliminary evidence that adjustment of cuff pressure guided by objective measurement as compared with subjective measurement or observation of the pressure alone, can prevent adverse effects including hoarseness, sore throat, lesions of the trachea and incidences of silent aspiration, as well as maintaining accurate cuff pressures.

\section{Conclusion}

Adjustment of cuff pressures guided by subjective measurement, or observation of the pressure value alone, may lead to patient-related adverse effects and inaccurate cuff pressures. It is recommended that an objective device be used.

\section{References}

1. Nseir S, Brisson H, Marquette C-H, Chaud P, Di Pompeo C, Diarra $\mathrm{M}$, Durocher A. Variations in endotracheal cuff pressure in intubated critically ill patients: prevalence and risk factors. Eur J Anaesthesiol 2009; 26:229-234.

2. Seegobin RD, van Hasselt GL. Endotracheal cuff pressure and tracheal mucosal blood flow: endoscopic study of effects of four large volume cuffs. Br Med J (Clin Res Ed) 1984; 288:965-968.

3. Rubio PA, Farrell EM, Bautista EM. Severe tracheal stenosis after brief endotracheal intubation. South Med J 1979; 72:1628-1629.

4. Stauffer JL, Olson DE, Petty TL. Complications and consequences of endotracheal intubation and tracheotomy. A prospective study of 150 critically ill adult patients. Am J Med 1981; 70:65-76.

5. Bouattour K, Prost-Lapeyre A, Hauw-Berlemont C, Diehl J-L, Guerot E. [A post-intubation tracheal rupture in intensive care unit]. Ann Fr Anesth Reanim 2014; 33:590-592.
6. Lim H, Kim JH, Kim D, Lee J, Son JS, Kim DC, Ko S. Tracheal rupture after endotracheal intubation-a report of three cases. Korean J Anesthesiol 2012; 62:277-280.

7. Alvarez-Maldonado P, Vidal E, Ceron-Diaz U. Tracheal ulcers due to endotracheal tube cuff pressure. J Bronchology Interv Pulmonol 2011; 18:288-289.

8. Combes X, Schauvliege F, Peyrouset O, Motamed C, Kirov K, Dhonneur G, Duvaldestin P. Intracuff pressure and tracheal morbidity: influence of filling with saline during nitrous oxide anesthesia. Anesthesiology 2001; 95:1120-1124.

9. Terashima H, Sakurai T, Takahashi S, Saitoh M, Hirayama K. [Postintubation tracheal stenosis; problems associated with choice of management]. Kyobu Geka 2002; 55:837-842.

10. Hameed AA, Mohamed H, Al-Mansoori M. Acquired tracheoesophageal fistula due to high intracuff pressure. Ann Thorac Med 2008; 3:23-25.

11. Estes RJ, Meduri GU. The pathogenesis of ventilator-associated pneumonia: I. Mechanisms of bacterial transcolonization and airway inoculation. Intensive Care Med 1995; 21:365-383.

12. Hamilton VA, Grap MJ. The role of the endotracheal tube cuff in microaspiration. Heart Lung 2012; 41:167-172.

13. Lau ACW, So HM, Tang SL, Yeung A, Lam SM, Yan WW. Prevention of ventilator-associated pneumonia. Hong Kong Med J 2015; 21:61-68.

14. Rello J, Sonora R, Jubert P, Artigas A, Rue M, Valles J. Pneumonia in intubated patients: role of respiratory airway care. Am J Respir Crit Care Med 1996; 154:111-115.

15. Curiel Garcia JA, Guerrero-Romero F, Rodriguez-Moran M. [Cuff pressure in endotracheal intubation: should it be routinely measured?]. Gac Med Mex 2001; 137:179-182.

16. Vyas D, Inweregbu K, Pittard A. Measurement of tracheal tube cuff pressure in critical care. Anaesthesia 2002; 57:275-277.

17. Peters JH, Hoogerwerf N. Prehospital endotracheal intubation; need for routine cuff pressure measurement? Emerg Med J 2013; 30:851-853.

18. Maboudi A, Abtahi H, Hosseini M, Tamadon A, Safavi E. Accuracy of endotracheal tube cuff pressure adjustment by fingertip palpation after training of intensive care unit nurses. Iran Red Crescent Med J 2013; 15:381-384.

19. Velasco Sanz TR, Ronda Delgado de la Fuente M, Sanchez de la Ventana AB, Reyes Merino Martinez M. [Cuff pressure control at the intensive care unit: influence of nursing professionals' training]. Enferm Intensiva 2015; 26:40-45.

20. Jiang N, Del Signore AG, lloreta AM, Malkin BD. Evaluation of a teaching tool to increase the accuracy of pilot balloon palpation for measuring tracheostomy tube cuff pressure. Laryngoscope 2013; 123:1884-1888.

21. Michlig SA. Anaesthetic staff cannot identify extremely high tracheal tube cuff pressures by palpation of the pilot balloon. $\mathrm{Br}$ J Anaesth 2013; 111:300-301.

22. Hoffman RJ, Parwani V, Hahn IH. Experienced emergency medicine physicians cannot safely inflate or estimate endotracheal tube cuff pressure using standard techniques. Am J Emerg Med 2006; 24:139-143.

23. Parwani V, Hoffman RJ, Russell A, Bharel C, Preblick C, Hahn $\mathrm{IH}$. Practicing paramedics cannot generate or estimate safe endotracheal tube cuff pressure using standard techniques. Prehosp Emerg Care 2007; 11:307-311.

24. Ganner C. The accurate measurement of endotracheal tube cuff pressures. Br J Nurs 2001; 10:1127-1134. 
25. Stewart SL, Secrest JA, Norwood BR, Zachary R. A comparison of endotracheal tube cuff pressures using estimation techniques and direct intracuff measurement. AANA J 2003; 71:443-447.

26. Braz JR, Navarro LH, Takata IH, Nascimento Junior P. Endotracheal tube cuff pressure: need for precise measurement. Sao Paulo Med J 1999; 117:243-247.

27. Fernandez R, Blanch L, Mancebo J, Bonsoms N, Artigas A. Endotracheal tube cuff pressure assessment: pitfalls of finger estimation and need for objective measurement. Crit Care Med 1990; 18:1423-1426.

28. Galinski M, Treoux V, Garrigue B, Lapostolle F, Borron SW, Adnet F. Intracuff pressures of endotracheal tubes in the management of airway emergencies: the need for pressure monitoring. Ann Emerg Med 2006; 47:545-547.

29. Talekar CR, Udy AA, Boots RJ, Lipman J, Cook D. Tracheal cuff pressure monitoring in the ICU: a literature review and survey of current practice in Queensland. Anaesth Intensive Care 2014; 42:761-770.

30. Moher D, Liberati A, Tetzlaff J, Altman DG. Preferred reporting items for systematic reviews and meta-analyses: the PRISMA statement. Br Med J 2009; 339:b2535.

31. Physiotherapy Evidence Database Scale. 1999 Physiotherapy Evidence Database website. From http://www.pedro.org.au/ english/downloads/pedro-scale/. Accessed March 2015.

32. Tooth L, Bennett S, McCluskey A, Hoffmann T, McKenna K, Lovarini M. Appraising the quality of randomized controlled trials: inter-rater reliability for the OTseeker evidence database. J Eval Clin Pract 2005; 11:547-555.

33. Maher CG, Sherrington C, Herbert RD, Moseley AM, Elkins M. Reliability of the PEDro scale for rating quality of randomized controlled trials. Phys Ther 2003; 83:713-721.

34. Ramadan M, Pushpanathan E, Sultan P. Should endotracheal cuff pressure be routinely measured during elective surgery? $\mathrm{Br} J$ Hosp Med (Lond) 2012; 73:538.

35. Valles J. Monitoring intra-cuff pressure in subglottic aspiration. Crit Care Med 2005; 33:1469-1470.

36. Nagdeve NG, Kelly K. Audit of tracheal tube cuff pressure measurement with a minimal occlusion technique of cuff inflation in a theatre setting. Br J Anaesth 2011;107:294P.

37. Gopalan P, Browning ST. Accuracy of finger-tip palpated tracheostomy tube cuff pressure readings among otolaryngologists. J Laryngol Otol 2005; 119:461-464.

38. Muñoz VE, Mojica S, et al. Comparison of the orotracheal tube cuff pressure estimated by palpation vs. the measurement taken with a manometer. Revista Ciencias de la Salud 2011; 9: 229-236.

39. Jain MK, Tripathi CB. Endotracheal tube cuff pressure monitoring during neurosurgery-manual vs automatic method. J Anaesthesiol Clin Pharmacol 2011; 27:358-361.

40. Kovaceric M, Pavicic AM et al. Monitoring tracheal tube cuff pressure reduces postoperative sore throat symptoms. Eur J Anaesthesiol 2013; 30: 54.

41. Arndt M, Hofmockel R, Benad G. [Sore throat after use of the laryngeal mask and intubation]. Anaesthesiol Reanim 1998; 23:44-48.

42. Goyal R, Kumar G, Waghray MR. Endotracheal tube cuff pressure monitoring in peripheral hospitals. Med J Armed Forces India 2006; 62: 243-245.

43. Modirian E, Ghafouri HB, Saeeidi H, Yasinzadeh M, Famouri S. Excessive endotracheal tube cuff pressure: is there any difference between emergency physicians and anesthesiologists? Signa Vitae 2012; 7:17-20.

44. Srinivasan D, Halsnad S, Anand R, Parmar S. Intraoperative tracheostomy tube cuff pressures: Pilot balloon palpation versus manometry. Accessed from Oral Oncol Supplement 2009; 3: 169.

45. Ansari L, Bohluli B, Mahaseni H, Valaei N, Sadr-Eshkevari P, Rashad A. The effect of endotracheal tube cuff pressure control on postextubation throat pain in orthognathic surgeries: a randomized double-blind controlled clinical trial. Br J Oral Maxillofac Surg 2014; 52:140-143.

46. Almarakbi WA, Kaki AM. Tracheal tube cuff inflation guided by pressure volume loop closure associated with lower postoperative cuff-related complications: Prospective, randomized clinical trial. Saudi J Anaesth 2014; 8:328-334.

47. Rubes D, Klein AA, Lips M, Rulisek J, Kopecky P, Blaha J et al. The effect of adjusting tracheal tube cuff pressure during deep hypothermic circulatory arrest: a randomised trial. Eur J Anaesthesiol 2014; 31:452-456.

48. Ryu JH, Han SS, Do SH, Lee JM, Lee SC, Choi ES. Effect of adjusted cuff pressure of endotracheal tube during thyroidectomy on postoperative airway complications: prospective, randomized, and controlled trial. World J Surg 2013; 37:786-791

49. Liu J, Zhang X, Gong W, Li S, Wang F, Fu S, Zhang M, Hang Y. Correlations between controlled endotracheal tube cuff pressure and postprocedural complications: a multicenter study. Anesth Analg 2010; 111:1133-1137.

50. Sajedi P, Maaroffi V. The macroscopic changes of tracheal mucosa following tight versus loose control of tracheal tube cuff pressure. Acta Anaesthesiol Sin 2002; 40:117-120.

51. Sridermma S, Limtangturakool S, Wongsurakiat $P$, Thamlikitkul V. Development of appropriate procedures for inflation of endotracheal tube cuff in intubated patients. J Med Assoc Thai 2007; 90 Suppl 2:74-78.

52. Morris LG, Zoumalan RA, Roccaforte JD, Amin MR. Monitoring tracheal tube cuff pressures in the intensive care unit: a comparison of digital palpation and manometry. Ann Otol Rhinol Laryngol 2007; 116:639-642.

53. Zand F, Nekooeian AA, Rohani M. Endotracheal tube cuff pressure monitoring in intensive care units. Iran Red Crescent Med J 2008; 10: 223-227.

54. Ayoub CM, Ghobashy A, Koch ME, McGrimley L, Pascale V, Qadir $S$ et al. Widespread application of topical steroids to decrease sore throat, hoarseness, and cough after tracheal intubation. Anesth Analg 1998; 87:714-716.

55. Hahnel J, Treiber H, Konrad F, Mutzbauer T, Steffen P, Georgieff M. Performance characteristics of a novel reusable intermediate-volume low-pressure cuffed endotracheal tube. Acta Anaesthesiol Scand 1994; 38:363-367.

56. Stout DM, Bishop MJ, Dwersteg JF, Cullen BF. Correlation of endotracheal tube size with sore throat and hoarseness following general anesthesia. Anesthesiology 1987; 67:419-421.

57. Edomwonyi NP, Ekwere IT, Omo E, Rupasinghe A. Postoperative throat complications after tracheal intubation. Ann Afri Med 2006; 5: 28-32.

58. van Zundert A, van Zundert T, Brimacombe J. Downfolding of the epiglottis during intubation. Anesth Analg 2010; 110:1246-1247.

59. Ratnaraj J, Todorov A, McHugh T, Cheng MA, Lauryssen C. Effects of decreasing endotracheal tube cuff pressures during neck 
retraction for anterior cervical spine surgery. J Neurosurg 2002; 97:176-179.

60. Loeser EA, Hodges M, Gliedman J, Stanley TH, Johansen RK, Yonetani D. Tracheal pathology following short-term intubation with low- and high-pressure endotracheal tube cuffs. Anesth Analg 1978; 57:577-579.

61. Stride PC. Postoperative sore throat: topical hydrocortisone. Anaesthesia 1990; 45:968-971.

62. Jensen PJ, Hommelgaard P, Sondergaard P, Eriksen S. Sore throat after operation: influence of tracheal intubation, intracuff pressure and type of cuff. Br J Anaesth 1982; 54:453-457.

63. Nordin $U$, Lindholm C E, Wolgast M. Blood flow in the rabbit tracheal mucosa under normal conditions and under the influence of tracheal intubation. Acta Anaesthesiol Scand 1977; 21:81-94.

64. Dullenkopf A, Gerber A, Weiss M. Fluid leakage past tracheal tube cuffs: evaluation of the new Microcuff endotracheal tube. Intensive Care Med 2003; 29:1849-1853.

65. Pitts R, Fisher D, Sulemanji D, Kratohvil J, Jiang Y, Kacmarek R. Variables affecting leakage past endotracheal tube cuffs: a bench study. Intensive Care Med 2010; 36:2066-2073.

66. Bernhard WN, Cottrell JE, Sivakumaran C, Patel K, Yost L, Turndorf H. Adjustment of intracuff pressure to prevent aspiration. Anesthesiology 1979; 50:363-366.

67. Touzot-Jourde G, Stedman NL, Trim CM. The effects of two endotracheal tube cuff inflation pressures on liquid aspiration and tracheal wall damage in horses. Vet Anaesth Analg 2005; 32:23-29.

68. Kako H, Goykhman A, Ramesh AS, Krishna SG, Tobias JD. Changes in intracuff pressure of a cuffed endotracheal tube during prolonged surgical procedures. Int J Pediatr Otorhinolaryngol 2015; 79:76-79.

69. Sole ML, Combs SM, Willis J. Changes in endotracheal cuff pressures over time. Crit Care Med 2003; 31: A144.

70. Sole ML, Poalillo FE, Byers JF, Ludy JE. Bacterial growth in secretions and on suctioning equipment of orally intubated patients: a pilot study. Am J Crit Care 2002; 11:141-149.

71. Sole ML, Penoyer DA, Su X, Jimenez E, Kalita SJ, Poalillo E et al. Assessment of endotracheal cuff pressure by continuous monitoring: a pilot study. Am J Crit Care 2009; 18:133-143.

72. Fu Y, Xi X. [Analysis on risk factors of endotracheal cuff under inflation in mechanically ventilated patients]. Zhonghua Wei Zhong Bing Ji Jiu Yi Xue 2014; 26:870-874.

73. Sole ML, Su X, Talbert S, Penoyer DA, Kalita S, Jimenez E et al. Evaluation of an intervention to maintain endotracheal tube cuff pressure within therapeutic range. Am J Crit Care 2011; 20:109-117.

74. Nseir S, Duguet A, Copin M-C, De Jonckheere J, Zhang M, Similowski T, Marquette $\mathrm{C}-\mathrm{H}$. Continuous control of endotracheal cuff pressure and tracheal wall damage: a randomized controlled animal study. Crit Care 2007; 11:R109.

75. Tu HN, Saidi N, Leiutaud T, Bensaid S, Menival V, Duvaldestin $P$. Nitrous oxide increases endotracheal cuff pressure and the incidence of tracheal lesions in anesthetized patients. Anesth Analg 1999; 89:187-190.

76. Hilding AC. Laryngotracheal damage during intratracheal anesthesia. Demonstration by staining the unfixed specimen with methylene blue. Ann Otol Rhinol Laryngol 1971; 80:565581.
77. Donnelly WH. Histopathology of endotracheal intubation. An autopsy study of 99 cases. Arch Pathol 1969; 88:511-520.

78. McHardy FE, Chung F. Postoperative sore throat: cause, prevention and treatment. Anaesthesia 1999; 54:444-453.

79. Nseir S, Zerimech F, Fournier C, Lubret R, Ramon P, Durocher A, Balduyck $M$. Continuous control of tracheal cuff pressure and microaspiration of gastric contents in critically ill patients. Am J Respir Crit Care Med 2011; 184:1041-1047.

80. Palmer LB. Ventilator-associated tracheobronchitis. Curr Respir Med Rev 2010; 6: 58-64.

81. Alvarez Lerma F, Sanchez Garcia M, Lorente L, Gordo F, Anon $J M$, Alvarez J et al. Guidelines for the prevention of ventilatorassociated pneumonia and their implementation. The Spanish 'Zero-VAP' bundle. Med Intensiva 2014; 38:226-236. 